\title{
The In Vitro Activity of a Range of Natural Bioflavonoids Against Five Species of Pathogenic Fish Bacteria
}

\author{
Gil Ha Yoon ${ }^{1,2 *}$, Sarah Al Jufaili², Aliya Al Ghabshi², \\ and Nashwa Al Mazrooei ${ }^{2}$ \\ ${ }^{1,2}$ Department of Marine Science and Fisheries, College of Agricultural and Marine Sciences, \\ Sultan Qaboos University, P.O. Box 34, Al-Khod 123, Muscat, Sultanate of Oman \\ ${ }^{2}$ Fishery Quality Control Center, Ministry of Agriculture and Fisheries Wealth \\ P.O. Box 427, P.C. 100, Muscat, Sultanate of Oman

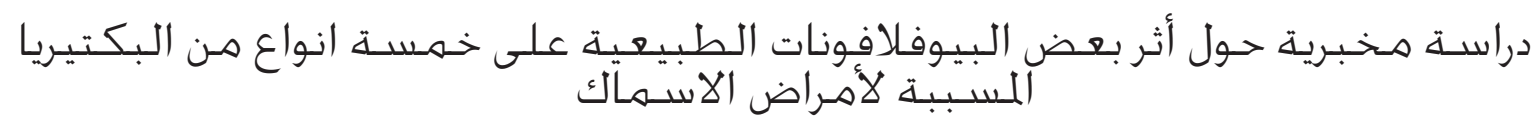

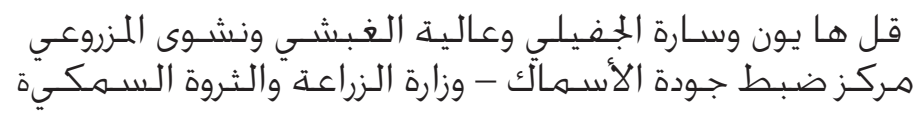

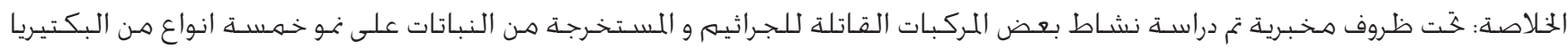

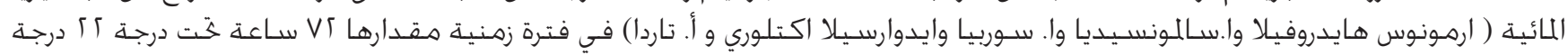

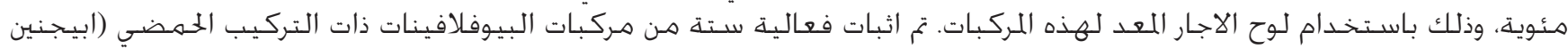

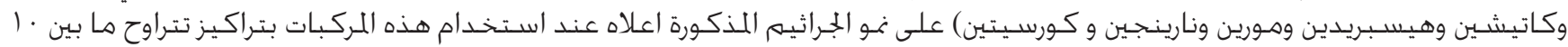

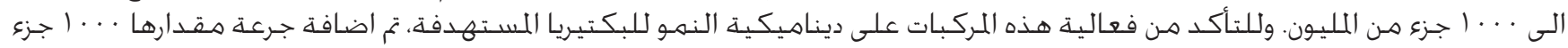

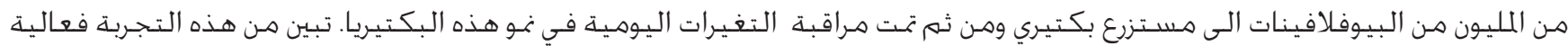

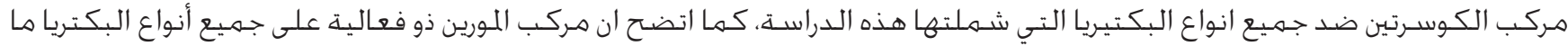

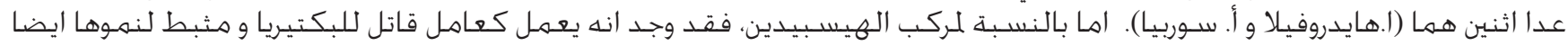

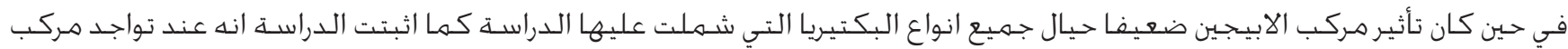

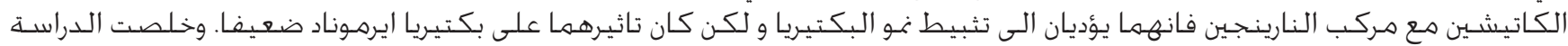

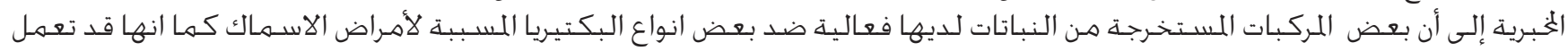

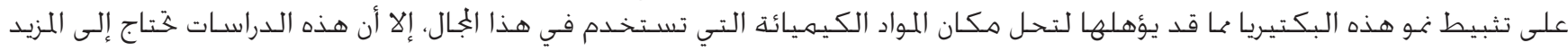

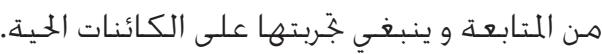

ABSTRACT: The in vitro antibacterial activity of thirty two plant-derived compounds ( 26 crude herbal extraction and 6 pure citrus-based bioflavonoids) were tested on five different species of aquatic bacterial pathogens (Aeromonas hydrophila, A. salmonicida, A. sobria, Edwardsiella ictaluri, and E. tarda) over a period of 72 hours at $22{ }^{\circ} \mathrm{C}$. From the agar diffusion test, six pure citrus-based bioflavonoids (apigenin, catechin, hesperidin, morin, naringin and quercetin) appeared to impact on growth when used at concentrations ranging from 10 ppm - 1000 ppm. To confirm their effect on the growth dynamics of each bacteria, a $1000 \mathrm{ppm}$ dose of the appropriate bioflavonoid was added to a bacterial culture and daily changes in culture growth were measured. Quercetin was found to be bacteriocidal against all the bacterial strains. Morin was found to be bacteriocidal against only 4 out of 6 strains while hesperidin was found to affect the growth of all the tested bacterial strains, working both as a bacteriocidal and as a bacteriostatic agent. Apigenin performed poorly and had no effect on the growth of any bacterial strain while catechin and naringin were found to be generally bacteriostatic in action but had little impact on the growth of the Aeromonad strains. From the current in vitro work, it was concluded that certain plant extracts do have an impact on the growth dynamics of select bacteria and show potential as alternatives to the use of antimicrobials, but further research is required to assess their performance in vivo.

Keywords: Fish disease, bioflavonoids, bacteria, Aeromonas, Edwardsiella.

\section{Introduction}

Bioflavonoids are a biologically active group of natural compounds that are present in a wide range of plants (twigs, leaves, bark, roots, spices, herbs, nuts, seeds, vegetables, flowers, fruits and buds) (Formica and Regelson, 1995; Peldt et al., 2001). The bioflavonoids and essential oils extracted from many plants have been used in traditional oriental medicine for thousands of years but it is only recently that they have been shown to possess a broad range of activities. Recently, there has been increased interest in the activity of certain plant-derived oils and flavonoids and in the possibility that they might represent antimicrobial activity against bacterial diseases affecting fish species. Categorised as "alternative medicines" rather than as first line treatments, little research has been done to explore the potential of using 
bioflavonoids as antimicrobials (Roth, et al., 1993; Hart et al., 1997) Due to the increased awareness and concern over antibiotic residues within farmed fish species new health management approaches which are complementary to existing management strategies are being investigated (Martin et al., 1998; Mayer and Hamann, 2002). Natural products such as the citrus derived bioflavonoids may have positive effects as antimicrobials against a number of bacterial fish pathogens. Pyrethrum, extracted from the flower heads of Chrysanthemum cinerariaefolium and C. coccineum, and the synthetic pyrethroid insecticides derived from them (e.g. cypermethrin and deltamethrin) have been used to control the ectoparasitic crustacean copepods Lepeophtheirus salmonis Krøyer, 1837 and Caligus elongatus von Nordmann, 1832 on Atlantic salmon, Salmo salar L. Both have shown to be efficacious (Roth, 2000; Boxaspen and Holm, 2001).

The aims of the current study were, therefore, to investigate the antimicrobial efficacy of a number of naturally-occurring bioflavonoids, particularly those from within the citrus bioflavonoids (e.g. hesperidin, naringin and quercetin). The discovery of effective biocides for the treatment of fish pathogens would, therefore, have the potential to make a significant contribution to the health management strategies currently employed in the control of certain fish diseases.

\section{Materials and Methods}

\section{Plant Extract Preparation}

The bacteriocidal activity of twenty-six crude plant extracts, seven pure bioflavonoids and a synthetic compound were assessed, in vitro, against cultures of five bacterial pathogens using an agar diffusion method (Table 1). The seven commercially produced bioflavonoids (catechin $\mathrm{C} 15 \mathrm{H} 14 \mathrm{O} 6$, hesperidin $\mathrm{C} 28 \mathrm{H} 34 \mathrm{O} 15$, morin C15H10O7, quercetin $\mathrm{C} 15 \mathrm{H} 10 \mathrm{O} 7$ and rutin $\mathrm{C} 27 \mathrm{H} 30 \mathrm{O} 16$, apigenin $\mathrm{C} 15 \mathrm{H} 10 \mathrm{O} 5$ and naringin $\mathrm{C} 27 \mathrm{H} 32 \mathrm{O} 14$ from Sigma-Aldrich, Poole, UK) were prepared by dissolving $1 \mathrm{~g}$ of the pure bioflavonoid in $5 \mathrm{ml} 0.25 \mathrm{M} \mathrm{NaOH}$ before diluting them to the appropriate concentration for testing $(10 \mathrm{ppm}-100 \%)$. Quercetin was prepared in distilled water. Crude plant extracts were prepared by grinding $10 \mathrm{~g}$ of each dried plant product in a pestle and mortar and then adding the ground fraction to $200 \mathrm{ml}$ of distilled water and boiling the mixture until the volume had reduced to 100 $\mathrm{ml}$. Where fresh plants were available for study, $20 \mathrm{~g}$ of each fresh plant was homogenized using a Hamilton Beach Model no. 909S blender with $100 \mathrm{ml}$ distilled water. The collected liquid fraction was then filtered through $20 \mu \mathrm{m}$ plastic mesh. The filtrate was regarded as $100 \%$ and lower concentrations were prepared as required.

\section{Selection of Bacterial Species and in vitro Assessment by Agar Diffusion}

Five bacterial species were purchased from the National Collection of Industrial Bacteria (NCIMB) and pure
Table 1. Details of the plant extracts, pure bioflavonoids, bioflavonoid complexes and synthetic compounds used in the current study.

\begin{tabular}{|c|c|c|}
\hline Scientific Name & Common Name & $\begin{array}{c}\text { Tested } \\
\text { Concentration }\end{array}$ \\
\hline i) Crude plant extracts & & $(\%)$ \\
\hline Allium сера & Onion & $1-5$ \\
\hline Angelica gigas & Angelica & $1-5$ \\
\hline Allium sativum & Garlic & $2-100$ \\
\hline Bambusicola thoracia & Chinese bamboo & $1-5$ \\
\hline Capsicum annuum & Chili & $2-100$ \\
\hline Cinnamomum verum & Cinnamon & $2-100$ \\
\hline Citrus aurantiifolia & Lime seed & $2-100$ \\
\hline Cnidium officinale & Cheonkung & $2-100$ \\
\hline Codonopsis pilosula & Deng shen & $2-100$ \\
\hline Digitalis purpurea & Common foxglove & $2-100$ \\
\hline Dioscorea opposite & Yam & $2-100$ \\
\hline Glycyrrhiza glabra & Liquorice & $2-100$ \\
\hline Lavandula angustifolia & Lavendar & $2-100$ \\
\hline Lippa alba & Alba & $2-100$ \\
\hline Maximowiczia typica & Omija & $2-100$ \\
\hline Mentha spicata & Spearmint & $2-100$ \\
\hline Ocimum basilicum & Basil & $2-100$ \\
\hline Paeonia obovata & White peony & $2-100$ \\
\hline Panax ginseng & Ginseng & $2-100$ \\
\hline Pimpinella vulgare & Aniseed & $2-100$ \\
\hline Poria cocos & Hoelen & $2-100$ \\
\hline Rosmarinus officinalis & Rosemary & $2-100$ \\
\hline Petroselinum crispum & Parsley & $2-100$ \\
\hline Wasabia japonica & Wasabi & $1-5$ \\
\hline Yucca spp. & Yucca & $1-5$ \\
\hline Zingiber officinale & Ginger & $2-100$ \\
\hline $\begin{array}{l}\text { ii) Purified bioflavonoids } \\
\text { Apigenin }\end{array}$ & & $\begin{array}{c}(\mathrm{ppm}) \\
10-1000\end{array}$ \\
\hline Catechin & & $10-1000$ \\
\hline Hesperidin & & $10-1000$ \\
\hline Morin & & $10-1000$ \\
\hline Naringin & & $10-1000$ \\
\hline Quercetin & & $10-1000$ \\
\hline Rutin & & $10-1000$ \\
\hline $\begin{array}{l}\text { iii) Synthetic biocides } \\
\text { DDQ }\end{array}$ & & $\begin{array}{c}(\mathrm{ppm}) \\
10-1000\end{array}$ \\
\hline
\end{tabular}

cultures were used for this study. The bacterial species used were Aeromonas hydrophila (NCIMB 1134), A. sobria (NCIMB 12065), A. salmonicida (NCIMB 13161), Edwardsiella ictaluri (NCIMB 13272) and E. tarda (NCIMB 2074). All cultures were grown on general purpose TSA (Tryptone soya agar, Oxoid U.K.) at the appropriate temperatures. Single colonies were identified following the techniques described by Frerichs and Millar (1993). For each bioflavonoid, a range of concentrations were tested $(10 \mathrm{ppm}-100 \%)$ in triplicate, by mixing 10 $\mathrm{ml}$ of the appropriate bioflavonoid concentration with 10ml of ISA (Iso-Sensitest Agar, Difco UK) media on each plate. For inoculation, a sub-sample of each pure cultured test bacteria was resuspended in $5 \mathrm{ml}$ TSB (Tryptic Soy Broth, Oxoid) and incubated for $24 \mathrm{hrs}$ prior to their inoculation onto ISA-flavonoid plates using a Denley multi-point inoculator. A series of control plates were also included in the study. All the inoculated plates were then maintained at $22{ }^{\circ} \mathrm{C}$ for $48-72 \mathrm{hrs}$ after which 
the growth of each bacterium against each concentration of bioflavonoid was recorded and compared against the control series of plates. Bacterial colony growth on each plate was scored as either (-) no growth, (+) weak growth, $(++)$ medium growth or $(+++)$ strong growth. Scores were given after three researchers gave their results based on comparing the growth patterns with the control plates.

\section{Bacteriocidal Assessment of the Most Efficacious Bioflavonoids}

Following the preliminary in vitro assessment of the selected bioflavonoids by the agar diffusion method, the most efficacious compounds were characterised further to establish whether their mode of action was bacteriocidal or bacteriostatic. To test this, a 1000 ppm dose of the most efficacious compounds identified from the disc diffusion assay: apigenin, catechin, hesperidin, morin, naringin and quercetin were added individually to each species of bacteria cultured in TSB (Oxoid UK) media. Each bacterial culture had a control (TSB + bacteria only) and cultures dosed with 5 ppm DDQ (di- $n$-decyldimethylammonium chloride) (Mackie Pharmaceuticals, UK) were employed as s a positive control. DDQ, a synthetic compound, appeared to be effective against all the bacteria species that were used in the in vitro testing when used at doses of $10 \mathrm{ppm}$. The culture broth tubes were then maintained at $22{ }^{\circ} \mathrm{C}$ and the turbidity of each tube was measured daily for a period of 8 days using a spectrophotometer at $610 \mathrm{~nm}$ wavelength (triplicate readings for each culture on each day) to estimate bacterial growth.

\section{Results}

Efficacy of the Selected Bioflavonoids by in vitro Agar Diffusion Against Bacterial Fish Pathogens

The efficacy of each bioflavonoid over the range of concentrations is presented in Tables 2 and 3. Catechin was also effective against different species of Aeromonas but at varied concentrations; $10 \mathrm{ppm}$ against $A$. salmonicida, 1000 ppm against $A$. sobria and yet apparently totally ineffective against $A$. hydrophila. The most effective bioflavonoid against E. tarda and E. ictaluri was 100 ppm of catechin (Table 3).

\section{Bacteriocidal Assessment of the Most Efficacious Bioflavonoids}

From the agar diffusion trial (Tables 2 and 3), it appeared that the six pure bioflavonoids, apigenin, catechin, hesperidin, morin, naringin and quercetin were the most efficacious compounds in inhibiting bacterial growth in vitro. The synthetic compound, DDQ, was found to be effective at concentrations of 10-1000 ppm (Table 3) against all the bacteria that were used in the agar diffusion trial and was tested alongside the pure bioflavonoids but at a lower dose of $5 \mathrm{ppm}$. The growth of the bacteria was measured daily spectrophotometrically and the data are presented in Figures 1-5. By comparing the results obtained for this aspect of the study with those obtained from the agar diffusion trials, it can be seen that a $1000 \mathrm{ppm}$ dose of quercetin had the broadest activity demonstrating a bacteriocidal effect against all bacteria that were tested. Hesperidin was also found to display broad activity, more so than was detected by the agar diffusion method and notably in its action against $A$. sobria (Figure 3 ). From the agar diffusion trials, higher doses of $1000 \mathrm{ppm}$ had an impact on both species of Edwardsiella. Incubation with apigenin did not affect the growth of any of the bacterial species tested (Table 3; Figures 4 and 5). A lower dose of DDQ, likewise, failed to impact on the growth and survival of any of the bacterial species over the test period. A 1000 ppm dose of morin was also found to have broad bacteriocidal activity except against $A$. hydrophila and $A$. sobria. The performance of catechin and naringin was lower and essentially bacteriostatic when used at $1000 \mathrm{ppm}$. Of the bacteria tested, A. hydrophila, was less affected by the pure bioflavonoids compared with the other bacterial species.

\section{Discussion}

This study set out to investigate the efficacy of 26 crude plant extracts and 6 pure bioflavonoids in their ability to affect the growth of several pathogenic species of aquatic bacteria. The bacterial species selected are pathogenic in a wide range of fish species of economic importance within global aquaculture.

Of the plant compounds tested by agar diffusion, it appeared that it was the synthetic compound DDQ and the pure bioflavonoid compounds that gave the most efficacious results. When these were tested further in broth culture, the flavonols quercetin and morin, and the flavone glycoside hesperidin, emerged as the most effective, in terms of their bacteriocidal activity. Paradoxically, quercetin which displayed efficacy against $A$. salmonicida only in the agar diffusion trial, displayed the broadest activity in broth culture, and interestingly, was the only water soluble, pure bioflavonoid that was tested. While the lipid solubility of certain products, notably the essential oils, might be improved through the use of detergents, the medium in which the compounds are assessed may also impact on the true activity of the compounds under test. A study by Remmal et al. (1993), for example, suggested that the activity of certain essential oils, in particular clove and oregano oils, were significantly reduced when added to agar as opposed to ethanol or Tween- 80 .

From the results presented here, it appears that certain compounds, notably quercetin, perform differently when assessed in different media. Interestingly, though, high doses of quercetin did not have an effect against the two Edwardsiella species in this study a $1 \%$ solution prepared from a crude extract of onions (A. cepa), known to be one of the richest sources of quercetin (284-486 mg/kg; Hertog and Feskens, 1993) reduced growth of both bacterial species. Morin is a ubiquitous secondary metabolite found in plants (Harborne and Williams, 2000) and although 
Table 2. The efficacy of the crude plant extracts were tested against five pathogenic bacterial species found in fish. The data for each compound and concentration represents the average result obtained from two replicate plates except the control which is based on the average results of multiple plates. The growth of bacteria on each plate is scored as either: $(+++)$ strong growth, $(++)$ medium growth, $(+)$ weak growth or (-) no growth.

\begin{tabular}{|c|c|c|c|c|c|}
\hline $\begin{array}{l}\text { Compound } \\
(\%)\end{array}$ & $\begin{array}{l}\text { Aeromonas } \\
\text { hydrophyla }\end{array}$ & $\begin{array}{l}\text { Aeromonas } \\
\text { salmonicida }\end{array}$ & $\begin{array}{l}\text { Aeromonas } \\
\text { sobria }\end{array}$ & $\begin{array}{c}\text { Edwardsiella } \\
\text { ictaluri }\end{array}$ & $\begin{array}{c}\text { Edwardsiella } \\
\text { tarda }\end{array}$ \\
\hline \multicolumn{6}{|l|}{ A. сера } \\
\hline 1 & ++ & ++ & +++ & + & + \\
\hline 2 & ++ & ++ & +++ & + & + \\
\hline 5 & ++ & ++ & +++ & + & + \\
\hline \multicolumn{6}{|l|}{ A. gigas } \\
\hline 1 & +++ & ++ & +++ & + & + \\
\hline 2 & +++ & ++ & +++ & + & + \\
\hline 5 & +++ & ++ & +++ & + & + \\
\hline \multicolumn{6}{|l|}{ A. sativum } \\
\hline 2 & +++ & ++ & +++ & + & + \\
\hline 5 & +++ & ++ & +++ & + & + \\
\hline 100 & - & - & - & - & - \\
\hline \multicolumn{6}{|l|}{ B. throracia } \\
\hline 2 & +++ & +++ & +++ & +++ & +++ \\
\hline 5 & +++ & +++ & +++ & +++ & +++ \\
\hline 100 & +++ & +++ & + & ++ & ++ \\
\hline \multicolumn{6}{|l|}{ C. аппиит } \\
\hline 1 & +++ & +++ & +++ & +++ & +++ \\
\hline 2 & +++ & +++ & +++ & +++ & +++ \\
\hline 5 & +++ & +++ & +++ & +++ & +++ \\
\hline \multicolumn{6}{|c|}{ C. aurantiifolia } \\
\hline 2 & +++ & ++ & ++ & ++ & + \\
\hline 5 & ++ & - & +++ & + & - \\
\hline 100 & - & - & - & - & - \\
\hline \multicolumn{6}{|l|}{ C. officinale } \\
\hline 2 & +++ & ++ & +++ & + & + \\
\hline 5 & +++ & ++ & +++ & + & + \\
\hline 100 & +++ & ++ & +++ & + & + \\
\hline \multicolumn{6}{|l|}{ C. pilosula } \\
\hline 2 & +++ & ++ & +++ & ++ & ++ \\
\hline 5 & +++ & ++ & +++ & ++ & ++ \\
\hline 100 & +++ & ++ & +++ & ++ & ++ \\
\hline \multicolumn{6}{|l|}{ C. verum } \\
\hline 2 & +++ & +++ & +++ & ++ & ++ \\
\hline 5 & +++ & +++ & +++ & ++ & ++ \\
\hline 100 & - & - & - & - & - \\
\hline \multicolumn{6}{|l|}{ D. opposite } \\
\hline 2 & +++ & ++ & +++ & + & + \\
\hline 5 & +++ & ++ & +++ & + & + \\
\hline 100 & +++ & ++ & +++ & + & + \\
\hline \multicolumn{6}{|l|}{ D. purpurea } \\
\hline 2 & +++ & ++ & +++ & + & + \\
\hline 5 & +++ & ++ & +++ & + & + \\
\hline 100 & ++ & - & ++ & - & - \\
\hline \multicolumn{6}{|l|}{ G. glabra } \\
\hline 2 & +++ & +++ & +++ & +++ & +++ \\
\hline 5 & +++ & +++ & +++ & +++ & +++ \\
\hline 100 & +++ & +++ & +++ & +++ & +++ \\
\hline \multicolumn{6}{|l|}{ L. alba } \\
\hline 2 & +++ & +++ & +++ & + & + \\
\hline 5 & +++ & +++ & +++ & + & + \\
\hline 100 & ++ & + & + & + & + \\
\hline
\end{tabular}


Table $2 \ldots . .$.

\begin{tabular}{|c|c|c|c|c|c|}
\hline $\begin{array}{l}\text { Compound } \\
(\%)\end{array}$ & $\begin{array}{l}\text { Aeromonas } \\
\text { hydrophyla }\end{array}$ & $\begin{array}{l}\text { Aeromonas } \\
\text { salmonicida }\end{array}$ & $\begin{array}{l}\text { Aeromonas } \\
\text { sobria }\end{array}$ & $\begin{array}{c}\text { Edwardsiella } \\
\text { ictaluri }\end{array}$ & $\begin{array}{c}\text { Edwardsiella } \\
\text { tarda }\end{array}$ \\
\hline \multicolumn{6}{|l|}{ L. angustifolia } \\
\hline 2 & +++ & +++ & +++ & +++ & +++ \\
\hline 5 & +++ & +++ & +++ & +++ & +++ \\
\hline 100 & +++ & +++ & +++ & +++ & +++ \\
\hline \multicolumn{6}{|l|}{ M. spicata } \\
\hline 2 & +++ & +++ & +++ & +++ & +++ \\
\hline 5 & +++ & +++ & +++ & +++ & +++ \\
\hline 100 & +++ & +++ & +++ & +++ & +++ \\
\hline \multicolumn{6}{|l|}{ M. typica } \\
\hline 2 & +++ & ++ & +++ & + & + \\
\hline 5 & +++ & ++ & +++ & + & + \\
\hline 100 & - & - & - & - & - \\
\hline \multicolumn{6}{|l|}{ O. basilicum } \\
\hline 2 & +++ & +++ & +++ & +++ & +++ \\
\hline 5 & +++ & +++ & +++ & +++ & +++ \\
\hline 100 & +++ & +++ & +++ & +++ & +++ \\
\hline \multicolumn{6}{|l|}{ P. cocos } \\
\hline 2 & +++ & ++ & +++ & + & + \\
\hline 5 & +++ & ++ & +++ & + & + \\
\hline 100 & +++ & ++ & +++ & + & + \\
\hline \multicolumn{6}{|l|}{ P. crispum } \\
\hline 2 & +++ & +++ & +++ & +++ & +++ \\
\hline 5 & +++ & +++ & +++ & +++ & +++ \\
\hline 100 & +++ & +++ & +++ & +++ & +++ \\
\hline \multicolumn{6}{|l|}{ P. ginseng } \\
\hline 2 & +++ & +++ & +++ & ++ & ++ \\
\hline 5 & +++ & +++ & +++ & + & + \\
\hline 100 & +++ & +++ & +++ & + & + \\
\hline \multicolumn{6}{|l|}{ P. obovata } \\
\hline 2 & +++ & ++ & +++ & + & + \\
\hline 5 & +++ & ++ & +++ & + & + \\
\hline 100 & +++ & ++ & +++ & + & + \\
\hline \multicolumn{6}{|l|}{ P. vulgare } \\
\hline 2 & +++ & +++ & +++ & +++ & +++ \\
\hline 5 & +++ & +++ & +++ & +++ & +++ \\
\hline 100 & - & - & - & - & - \\
\hline \multicolumn{6}{|l|}{ R. officinalis } \\
\hline 2 & +++ & +++ & +++ & +++ & +++ \\
\hline 5 & +++ & +++ & +++ & +++ & +++ \\
\hline 100 & +++ & +++ & +++ & +++ & +++ \\
\hline \multicolumn{6}{|l|}{$W$. japonica } \\
\hline 1 & ++ & ++ & +++ & + & + \\
\hline 2 & ++ & ++ & +++ & + & + \\
\hline 5 & ++ & + & ++ & ++ & + \\
\hline \multicolumn{6}{|l|}{ Yucca spp. } \\
\hline 1 & ++ & ++ & +++ & ++ & ++ \\
\hline 2 & ++ & ++ & +++ & ++ & ++ \\
\hline 5 & - & - & - & - & - \\
\hline \multicolumn{6}{|l|}{ Z. officinale } \\
\hline 2 & +++ & +++ & +++ & +++ & +++ \\
\hline 5 & +++ & +++ & +++ & +++ & +++ \\
\hline 100 & +++ & +++ & +++ & +++ & +++ \\
\hline$\left(\mathrm{TSA}+\mathrm{dH}_{2} 0\right)^{1}$ & +++ & +++ & +++ & +++ & +++ \\
\hline$(\mathrm{TSA}+\mathrm{NaOH})^{2}$ & +++ & +++ & +++ & +++ & +++ \\
\hline
\end{tabular}

143 replicates used

${ }^{2} 12$ replicates used 
Table 3. The efficacy of seven pure bioflavonoids and a synthetic compounds against five pathogenic bacteria, the genera Aeromonas and Edwardsiella. The data for each compound and concentration represents the average result obtained from two replicate. The growth of bacteria on each plate is scored as either: $(+++)$ strong growth, $(++)$ medium growth, (+) weak growth or (-) no growth.

\begin{tabular}{|c|c|c|c|c|c|}
\hline $\begin{array}{l}\text { Compound } \\
(\mathrm{ppm})\end{array}$ & $\begin{array}{l}\text { Aeromonas } \\
\text { hydrophyla }\end{array}$ & $\begin{array}{l}\text { Aeromonas } \\
\text { salmonicida }\end{array}$ & $\begin{array}{l}\text { Aeromonas } \\
\text { sobria }\end{array}$ & $\begin{array}{c}\text { Edwardsiella } \\
\text { ictaluri }\end{array}$ & $\begin{array}{c}\text { Edwardsiella } \\
\text { tarda }\end{array}$ \\
\hline \multicolumn{6}{|l|}{ Apigenin } \\
\hline 10 & +++ & + & +++ & + & + \\
\hline 100 & +++ & + & +++ & + & + \\
\hline 1000 & +++ & + & +++ & - & - \\
\hline \multicolumn{6}{|l|}{ Catechin } \\
\hline 10 & +++ & ++ & +++ & + & + \\
\hline 100 & +++ & ++ & +++ & - & - \\
\hline 1000 & +++ & - & - & - & - \\
\hline \multicolumn{6}{|l|}{$\mathrm{DDQ}^{\mathrm{TM}}$} \\
\hline 10 & +++ & - & +++ & - & - \\
\hline 100 & + & - & - & - & - \\
\hline 1000 & - & - & - & - & - \\
\hline \multicolumn{6}{|l|}{ Hesperidin } \\
\hline 10 & +++ & ++ & +++ & + & + \\
\hline 100 & +++ & ++ & +++ & + & + \\
\hline 1000 & +++ & + & +++ & - & - \\
\hline \multicolumn{6}{|l|}{ Morin } \\
\hline 10 & ++ & - & +++ & ++ & + \\
\hline 100 & ++ & - & +++ & ++ & + \\
\hline 1000 & ++ & - & +++ & ++ & - \\
\hline \multicolumn{6}{|l|}{ Naringin } \\
\hline 10 & +++ & ++ & +++ & + & + \\
\hline 100 & +++ & ++ & +++ & + & + \\
\hline 1000 & +++ & ++ & +++ & + & + \\
\hline \multicolumn{6}{|l|}{ Quercetin } \\
\hline 10 & ++ & - & +++ & ++ & + \\
\hline 100 & ++ & - & $\begin{array}{l}n+4 \\
++4\end{array}$ & ++ & $\begin{array}{l}+ \\
+\end{array}$ \\
\hline 1000 & ++ & - & +r+ & ++ & + \\
\hline \multicolumn{6}{|l|}{ Rutin } \\
\hline 10 & +++ & ++ & +++ & + & + \\
\hline 100 & +++ & ++ & +++ & + & + \\
\hline 1000 & +++ & + & +++ & - & - \\
\hline$\left(\mathrm{TSA}+\mathrm{dH}_{2} 0\right)^{1}$ & +++ & +++ & +++ & ++ & ++ \\
\hline$(\mathrm{TSA}+\mathrm{NaOH})^{2}$ & +++ & +++ & +++ & ++ & ++ \\
\hline
\end{tabular}




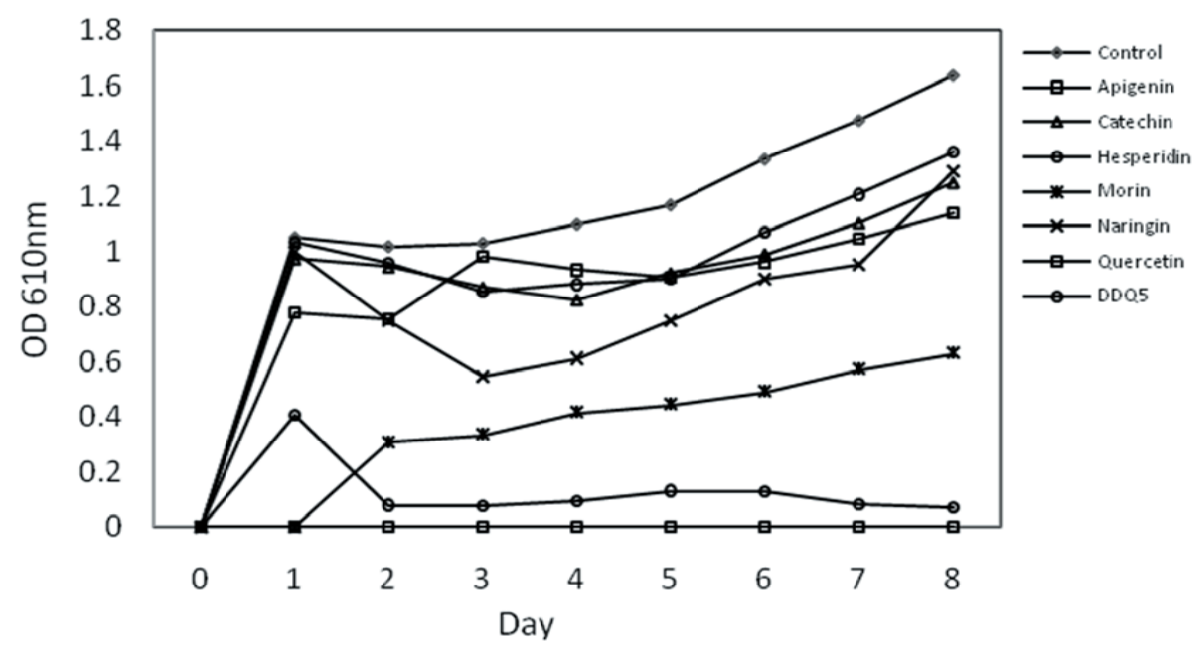

Figure 1. The growth of Aeromonas hydrophila in the presence of six different bioflavonoids, each at a concentration of 1000ppm, against time (days). The broth turbidity are measured against a control (bacteria + media) and 5ppm DDQ (a synthetic drug shown to be effective at doses of 10ppm).

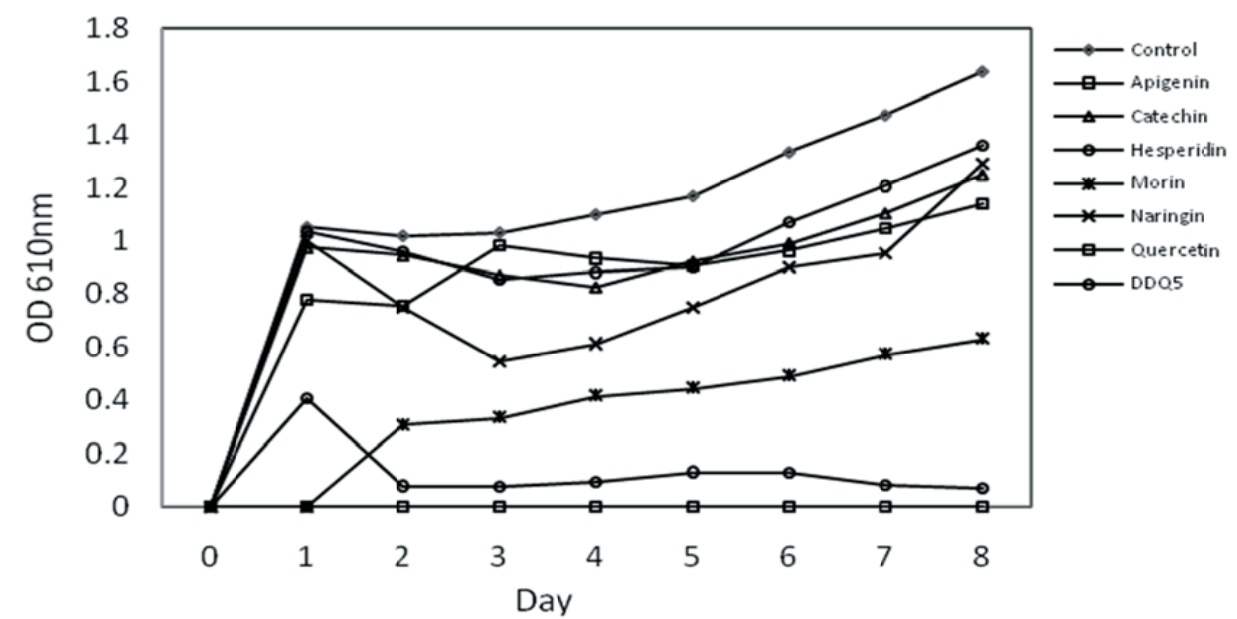

Figure 2. The growth of Aeromonas salmonicida in the presence of six different bioflavonoids, each at a concentration of 1000ppm, against time (days). The broth turbidity are measured against a control (bacteria + media) and 5ppm DDQ (a synthetic drug shown to be effective at doses of 10ppm).

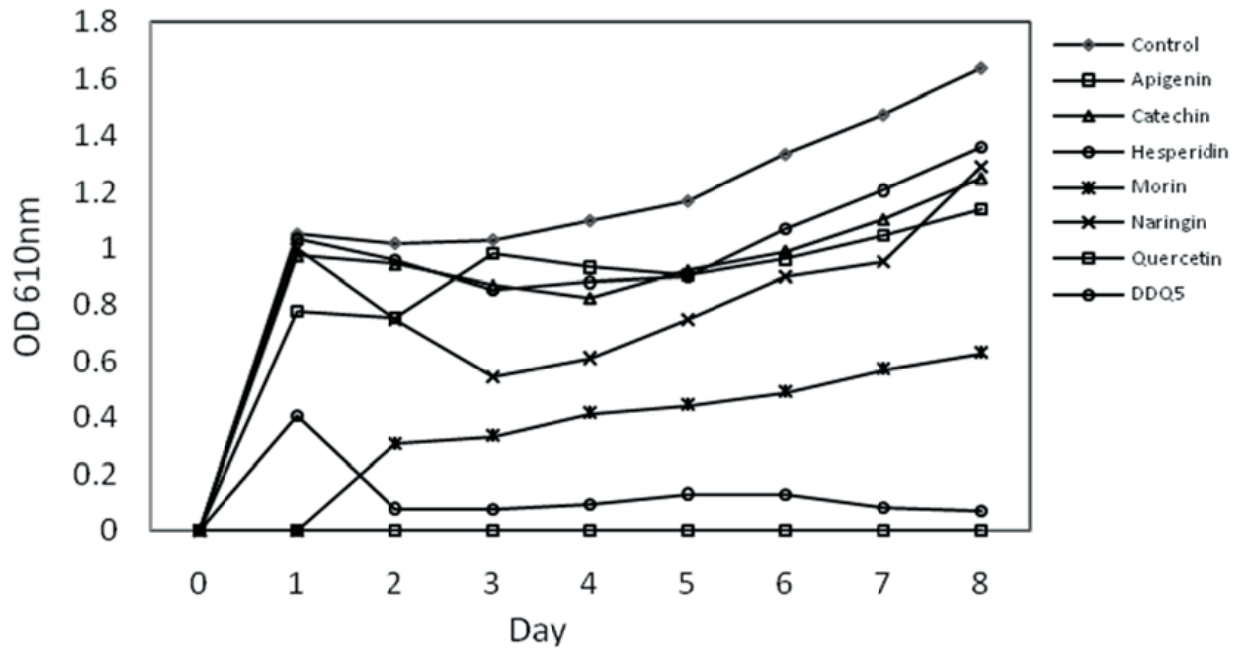

Figure 3. The growth of Aeromonas sobria in the presence of six different bioflavonoids, each at a concentration of 1000ppm, against time (days). The broth turbidity are measured against a control (bacteria + media) and 5ppm DDQ (a synthetic drug shown to be effective at doses of 10ppm). 


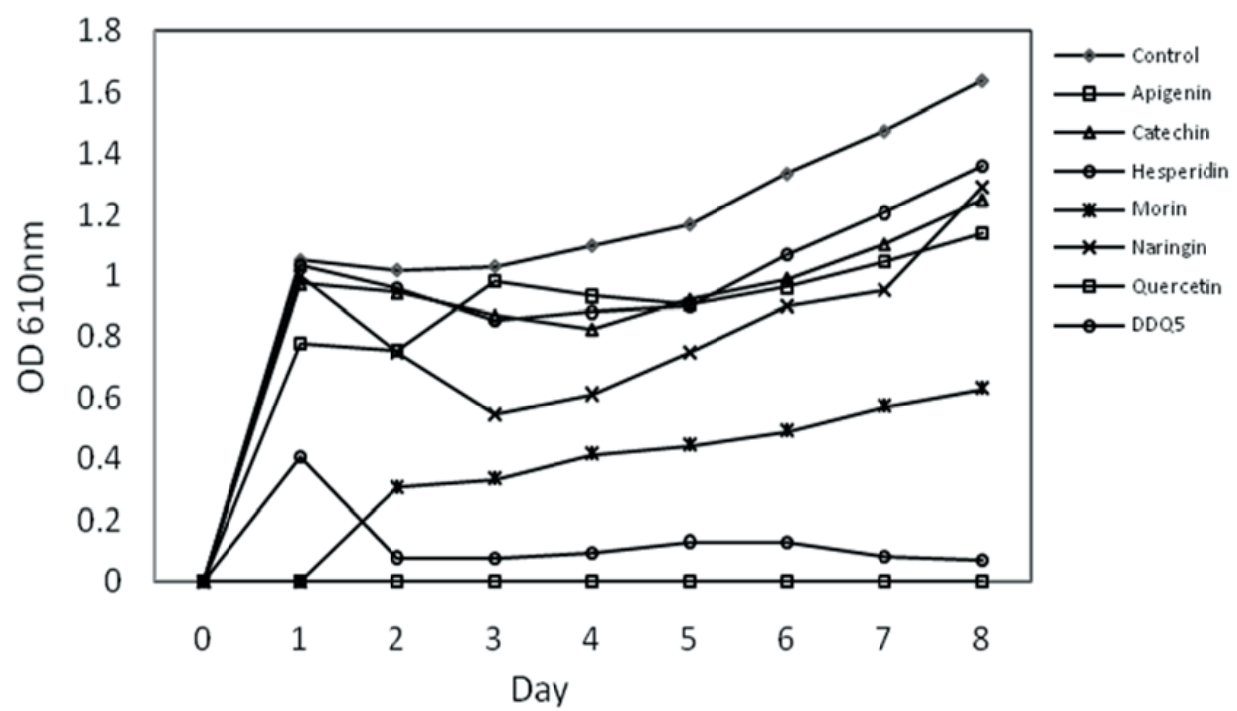

Figure 4. The growth of Edwardsiella ictaluri in the presence of six different bioflavonoids, each at a concentration of 1000ppm, against time (days). The broth turbidity are measured against a control (bacteria + media) and 5ppm DDQ (a synthetic drug shown to be effective at doses of 10ppm).

this flavonol displayed mixed results in the agar diffusion trial conducted within this study, a high dose (1000 ppm) appeared bacteriocidal to all but two strains of Aeromonas spp. (A. hydrophila and A. sobria) when tested in broth culture. The flavone glycoside hesperidin is an antioxidant and a predominant flavonoid commonly found in citrus fruits. While the actions of quercetin and morin were largely bacteriocidal in action against the bacterial species and strains under assessement, the responses to hesperidin were mixed showing both bacteriocidal and bacteriostatic effects. Mixed responses were also observed for catechin, hesperidin and morin against Aeromonas spp. and for hesperidin and naringin against Edwardsiella spp. Of the pure bioflavonoids that were tested in broth culture, only the flavone apigenin, failed to elicit any effect on any of the bacterial species. The agar diffusion tests suggested that a $1000 \mathrm{ppm}$ dose of apigenin might affect the growth of both Edwardisella species while a 1000 ppm dose of catechin might restrict the growth of A. sobria. At 1000 ppm, these were the highest doses that were tested and while these were ineffective in broth culture, the culture medium may play a role in affecting their efficacy. This suggests that higher doses are possibly required to exert an effect. The performance of DDQ in broth culture was disappointing and none of the results observed in the agar diffusion trial were mirrored in the broth culture trial.

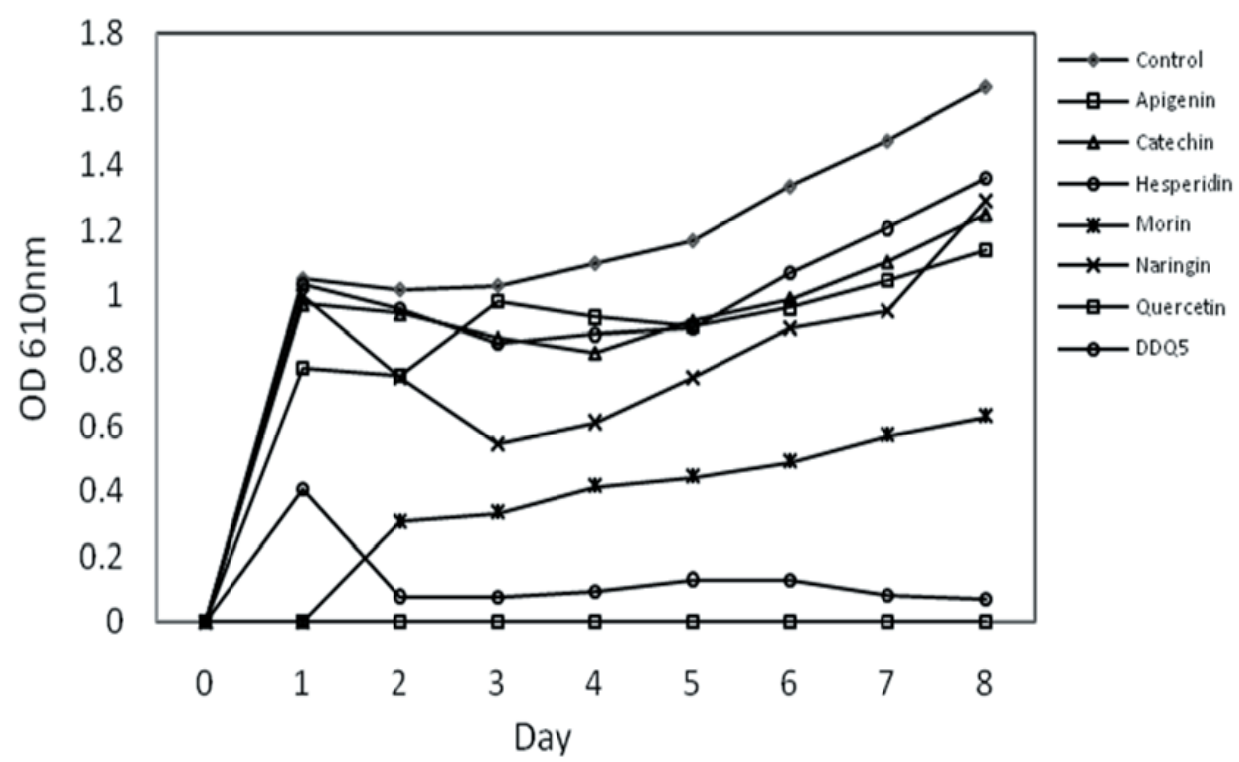

Figure 5. The growth of Edwardsiella tarda in the presence of six different bioflavonoids, each at a concentration of 1000ppm, against time (days). The responses are measured against a control (bacteria + media) and 5ppm DDQ (a synthetic drug shown to be effective at doses of 10ppm). 
The broth culture experiment, however, was significantly more sensitive in identifying bioflavonoids that exerted an effect on the different bacteria under test. Therefore, future tests may use the agar diffusion assay as a pre-screening method to evaluate the general activity of potentially useful compounds. These should then be followed up using the broth culture method which appears to be more sensitive, thus providing more accurate data.

Crude extracts taken from garlic (Allium sativum), cinnamon (Cinnamomum verum), lime seed (Citrus aurantiifolia), omija (Maximowiczia typica), aniseed (Pimpinella vulgare) and yucca (Yucca spp.) and to a lesser extent common foxglove (Digitalis purpurea) displayed broader antibacterial activity. Most of these were effective only when used in their crude extracted form although lower concentrations of Yucca $(<5 \%)$ appeared to effect growth. Of these, garlic and its active components allicin and ajoene, is arguably the best known since it displays a broad spectrum of activity against a range of bacteria, viruses and parasites (Ankri and Mirelman, 1999; Zenner et al., 2003; Anthony et al., 2005; Magi et al., 2005; Park et al., 2005). Similarly, cinnamon oil has been effectively used against, among others, intestinal flagellates and phthirapteran lice (Veal, 1996; Zenner et al., 2003; Anthony et al., 2005). Given that the agar diffusion trials have been successful in highlighting compounds which when tested further have been found to be efficacious, suggests that there is value in further evaluating the plants listed above shown to have a broad activity.

The results from this study indicated that some of the compounds tested had potential antimicrobial activity by reducing bacterial growth. It is not intended that natural compounds replace the need for antibiotics to treat bacterial disease outbreaks. It may be that the role of the naturallyderived products could be a complementary addition to the existing health management practices applied within a wide range of fish-farming systems. The natural products may be able to lower the bacterial loading of opportunistic pathogens within the water column, thus reducing their ability to cause disease. This in turn could lower the prevalence and spread of opportunistic pathogens within the production system resulting in fewer applications of antibiotics.

This study has demonstrated the efficacy of certain bioflavonoids against a range of bacteria commonly causing infections within fish in vitro, the next phase of research must focus on evaluating the efficacy of the best performing compounds in vivo. While the results from the agar diffusion tests and broth cultures provided an indication of effective doses of bioflavonoid, the minimum inhibitory concentration (MICs) of the bioflavonoids in vitro may require a greater magnitude in diets (Burt, 2004).

\section{References}

Ankri, S. and D. Mirelman. 1999. Antimicrobial properties of allicin from garlic. Microbes and Infection 1:125-129.
Anthony, J.P., L. Fyfe, and H. Smith. 2005. Plant active components - a resource for antiparasitic agents? Trends in Parasitology 21:462-468.

Boxaspen, K. and J.C. Holm. 2001. The development of pyrethrum-based treatments against the ectoparasitic salmon lice Lepeophtheirus salmonis in sea cage rearing of Atlantic salmon Salmo salar L. Aquaculture Research 32:701-707.

Burt, S. 2004. Essential oils: their antibacterial properties and potential applications in foods - a review. International Journal of Food Microbiology 94:223-253.

Formica, J.V. and W. Regelson. 1995. Review of the biology of quercitin and related bioflavonoids. Food and Chemical Toxicology 33:1061-1080.

Frerichs, G.N. and S.D. Millar. 1993. Manual for the Isolation and Identification of Fish Bacterial Pathogens. 55pp. Pisces Press. U.K.

Harborne, J.B. and C.A. Williams. 2000. Advances in flavonoid research since 1992. Phytochemistry 55: 481-504.

Hart, J.L., J.R.M. Thacker, J.C. Braidwood, N.R. Fraser, and J.E. Matthews. 1997. Novel cypermethrin formulation for the control of sea lice on salmon (Salmo salar). Veterinary Record 140:179-181.

Hertog, M.G.L. and E.J.M. Feskens. 1993. Dietary antioxidant flavonoids and risk of coronary heart disease: The Zutphen elderly study. Lancet 342:10071011.

Magi, E., H. Talvik, and T. Jarvis. 2005. In vivo studies of the effect of medicinal herbs on the pig nodular worm (Oesophagostomum spp.). Helminthologia 42:67-69.

Martin, T., L. Villaescusa, M. Gasquet, F. Delmas, C. Bartolome, A.M. Diaz-Lanza, E. Ollivier, and G. Balansard. 1998. Screening for protozoocidal activity of spanish plants. Pharmaceutical Biology 36:56-62.

Nijveldt, R.J., E. van Nood, D.E.C. van Hoorn, P.G. Boelens, K. van Norren, and van P.A.M. Leeuwen. 2001. Flavonoids: a review of probable mechanisms of action and potential applications. The American Journal of Clinical Nutrition 74:418-425.

Park, I.K., J.Y. Park, K.S. Choi, I.H. Choi, C.S. Kim, and S.C. Shin. 2005. Nematicidal activity of plant essential oils and components from garlic (Allium sativum) and cinnamon (Cinnamomum verum) oils against the pine wood nematode (Bursaphelenchus xylophilus). Nematology 7:764-774.

Remmal, A., T. Bouchikhi, A. Tantaoui-Elaraki, and M. Ettayebi. 1993. Inhibition of antibacterial activity of essential oils by Tween 80 and ethanol in liquid medium. Journal de Pharmacie de Belgique 48:352356.

Roth, M. 2000. The availability and use of chemotherapeutic sea lice control products. Contributions to Zoology 69:109-118.

Roth, M., R.H. Richards, and C. Sommerville. 1993. Current practices in the chemotherapeutic control of sea lice infestations in Aquaculture - a review. Journal of Fish Diseases 16:1-26.

Veal, L. 1996. The potential effectiveness of essential oils as a treatment for head lice, Pediculus humanus capitis. Complementary Therapies in Nursing and Midwifery 2: $97-101$. 
Zenner, L., M.P. Callait, C. Granier, and C. Chauve. 2003. In vitro effect of essential oils from Cinnamomum aromaticum, Citrus limon and Allium sativum on two intestinal flagellates of poultry, Tetratrichomonas gallinarum and Histomonas meleagridis. Parasite - Journal de la Societe Francaise de Parasitologie 10: 153-157.

Received: May 26, 2010

Accepted: September 19, 2010 